\title{
Determinan Jumlah Penduduk Miskin di Jawa Periode 2007-2015
}

\author{
(Determinant Total People of poverty in Java Period 2007-2015)
}

\author{
Mochammad Dwi Ainoer Rizzal, Mohammad Saleh ${ }^{1}$, Aisah Jumiati \\ Jurusan Ilmu Ekonomi Studi Pembangunan, Fakultas Ekonomi Dan Bisnis, Universitas Jember (UNEJ) \\ Jln. Kalimantan 37, Jember 68121 \\ Email: fe.m.saleh@unej.ac.id
}

\begin{abstract}
Abstrak
Kemiskinan merupakan salah satu masalah yang menghambat pertumbuhan ekonomi dan pembangunan nasional maupun regional. Oleh karena itu perlu dicari solusi untuk dapat mengurangi dan mengatasi permasalahan kemiskinan yang saat ini sedang terjadi. Tujuan dari penelitian ini untuk mengetahui besarnya pengaruh pengangguran, upah, dan Produk Domestik Regional Bruto (PDRB) terhadap kemiskinan di Pulau Jawa. Metode penelitian ini merupakan metode explanatory research. Unit analisis yang digunakan dalam penelitian ini adalah jumlah penduduk miskin di Pulau Jawa, faktor yang mempengaruhi kemiskinan diantaranya pengangguran, upah dan Produk Domestik Regional Bruto (PDRB). Data yang digunakan dalam penelitian ini adalah data sekunder. Hasil penelitian menunjukan bahwa pengangguran berpengaruh positif serta upah dan PDRB berpengaruh negatif dan signifikan terhadap kemiskinan. Dari hasil penelitian ini diharapkan selanjutnya mampu untuk memberikan referensi perbaikan terciptanya kesejahteraan masyarakat secara merata.
\end{abstract}

Kata Kunci : Penduduk miskin, Pengangguran, Upah, dan Produk Domestik Regional Bruto PDRB)

\begin{abstract}
Poverty is one of the problems that impede economic growth and national and regional development. It is therefore necessary to find solutions to reduce poverty and solve the problems that are being experienced. The purpose of this study to determine the influence of unemployment, wages and Gross Domestic Product (GDP) on poverty in Java. This research method is explanatory research method. The unit of analysis used in this study is the number of poor people in Java, factors affecting poverty include unemployment, wages and Gross Domestic Product (GDP). Data used in this research is secondary data. The results showed that the positive effect of unemployment and wages and GRDP a significant negative effect on poverty. From the results of this study are expected later able to provide references improvements creation of the welfare of society equally.
\end{abstract}

Keywords: People poverty, unemployment, wage, Gross Regional Domestic Product

\section{Pendahuluan}

Pembangunan ekonomi menjadi tolak ukur keberhasilan ekonmi suatu negara baik negara maju dan berkembang. Pembangunan adalah suatu proses menuju kearah yang lebih baik dan secara terus-menerus untuk dapat mencapai tujuan kesejahteraan, kemampuan berdaya saing, serta berkeadilan. Hidup layak merupakan hak asasi manusia yang telah diakui secara universal. Undang-undang dasar (UUD) 1945 telah mengamanatkan kepada tugas pokok seluruh komponen pemerintah Indonesia yaitu "Untuk memajukan kesejahteraan secara umum, mencerdaskan kehidupan bangsa serta untuk mewujudkan suatu keadilan sosial bagi seluruh rakyat Indonesia." Berarti hidup bebas tanpa adanya kemiskinan serta dapat menikmati kehidupan yang layak yang merupakan hak asasi setiap warga negara. Kemiskinan adalah ketidakmampuan seseorang untuk memenuhi standar hidup minimum yang telah ditentukan (Kuncoro, 1997).

Berbagai sumber meberikan standarisasi dalam penentuan standar minimum untuk pengklasifikasian kemiskinan. Besarnya ukuran standar minimum kemiskinan menurut Badan Pusat Statistik (BPS) Indonesia yakni ukuran standar kemiskinan yang didasarkan atas seberapa besar seseorang untuk memenuhi kebutuhan pada tingkat standar minimum. Standar minimum dapat dilihat dari seberapa besar seseorang untuk dapat membelanjakan pendapatannya agar dapat memenuhi standar minimum kebutuhan makanan dan non makanan mereka. Kebutuhan minimum makanan yang menjadi patokan yakni 2100 kalori per hari, sedangkan kebutuhan non makanan yang menjadi patokan untuk standar minimum kemiskinan yakni perumahan, sandang, aneka barang dan jasa (BPS, 1994). Masalah kemiskinan memiliki kombinasi masalah yang kompleks karena telah berhubungan dengan berbagai aspek kehidupan yang meliputi aspek sosial, ekonomi, budaya, serta aspek lainnya. Kemiskinan merupakan masalah multidimensi yang dihadapi oleh hampir seluruh negara dibelahan dunia. Indonesia sebagai negara berkembang tidak lepas dari masalah kemiskinan. Kemiskinan terjadi akibat jumlah penduduk yang padat sehingga terjadi kesenjangan ekonomi di negara berkembang. Kondisi tersebut menunjukkan bahwa perlu adanya regulasi yang direalisasikan pemerintah untuk mengentaskan permasalahan tersebut. Salah satu indicator pembangunan ekonomi dapat dilihat dari ukuran penurunan angka kemiskinan secara perlahan dan terhapusnya kemiskinan maka akan menjadi adil dan makmur sesuai dengan tujuan utama dari Pancasila (Soerjani, 1997).

Pada negara berkembang masalah jumlah penduduk miskin sangat sulit untuk diatasi. Jumlah penduduk miskin bahkan setiap tahunnya akan cenderung bertambah jika tidak ada solusi yang tepat dari pemerintah Indonesia. Banyak faktor yang memengaruhi meningkatnya jumlah penduduk miskin yang terjadi pada negara berkembang. Faktor-faktor tersebut

1 Penulis Korespondensi 
umumnya sangat berperan penting dalam memengaruhi angka kemiskinan yang ada. Pulau Jawa sebagai wilayah dengan penduduk terpadat di Indonesia tentunya sangat sulit untuk mengatasi masalahkemiskinan. Pulau Jawa di bagi menjadi 6 provinsi, yaitu provinsi Jawa Barat, provinsi Jawa Tengah, provinsi Jawa Timur, provinsi DKI Jakarta, provinsi DI Yogyakarta, dan provinsi Banten. Sebagai pulau dengan jumlah pendnduk miskin terbesar tentunya pemerintah di masing-masing provinsi harus sesegera mungkin mencari solusi sehingga permasalahan kemiskinan dapat teratasi. Faktor-faktor seperti tingkat pengangguran, upah, dan PDRB berperan penting dalam memengaruhi jumlah penduduk miskin yang ada di pulau Jawa. (Djojohadikusumo, 1994).

Banyaknya jumlah penduduk miskin di Indonesia disebabkan oleh beberapa faktor, antara lain tingkat pengangguran yang tinggi, upah yang rendah dan masih di bawah standar,Indeks Pembangunan Manusia yang yang mengalami penurunan, serta ketidakstabilan angka dari Produk Domestik Regional Bruto (Sallatang, 1986). Faktor-faktor tersebut memiliki peran sebagai penyebab kemiskinan di negara berkembang seperti Indonesia. Seseorang dapat dikatakan miskin apabila orang tersebut masih belum dapat memenuhi kebutuhannya. Upah yang tinggi dapat mengakibatkan konsumsi masyarakat mengalami peningkatan. Kemiskinan adalah ketidakcukupan seseorang dalam menerima pendapatan dan pemilikan kekayaan materil, tanpa adanaya mengabaikan standar atau ukuran fisiologi, psikologi dan sosial mereka (Sallatang, 1986). Pengangguran merupakan salah satu penyebab utama yang dapat mengakibatkan jumlah penduduk miskinsemakin meningkat. Semakin banyaknya pengangguran menyebabkan jumlah penduduk miskin semakin meningkat dikarenakan semakin meningkatnya masyarakat yang tidak dapat memenuhi kebutuhan hidupnya akibat tidak adanya pendapatan (Sukirno,2004:28).

\section{Metode}

Penelitian ini menggunakan metode penelitian deskriptif dan kuantitatifyaitu penelitian metode secara sistematis, faktual dan akurat mengenai objek yang ditelliti dan bertujuan untuk mengetahui ada tidaknya sifat hubungan antara dua variabel atau lebih serta menguji hipotesis. Data yang digunakan adalah data sekunder, dengan menggunakan data time series dari tahun 2007-2015, yaitu jumlah penduduk miskin sebagai variabel dependen dan pengangguran, upah dan PDRB sebagai variabel independen. Sumber Data diperoleh dari Badan Pusat Statistik Indonesia.

\section{Metode Analisis Regresi Data Panel}

Penelitian ini menggunakan data panel, yaitu gabungan antara data time series yang berdasarkan runtut waktu dan data cross section yang didasarkan pada jumlah pegamatan yang diteliti. Dapat dikatakan bahwa data panel merupakan kombinasi dari jumlah $\mathrm{N}$ unit spasial dan $\mathrm{T}$ yang merupakan periode waktu untuk menghasilkan set data $\mathrm{N} \quad \mathrm{x} \quad \mathrm{T}$ (Raselawati, 2011).Fungsinya dapat dinyatakan sebagai berikut :

$$
\mathrm{Y}=\mathrm{f}(\mathrm{X} 1, \mathrm{X} 2 \ldots \mathrm{Xn})
$$

Ada beberapa keuntungan yang diperoleh dengan menggunakan data panel yaitu data panel mampu memberikan data yang lebih banyak, lebih informative dan lebih memilki variabilitas sehingga akan menghasilkan degree of freedom yang lebih banyak dan lebih efisien (Baltagi 2005: 4).Model regresi yang digunakan dalam penelitian ini adalah sebagai berikut (Susilo, 2011) :

$$
\mathbf{Y}=\mathbf{b}_{0}+\mathbf{b}_{1} \mathbf{X}_{1}+\mathbf{b}_{2} \mathbf{X}_{2}+\mathbf{b}_{3} \mathbf{X}_{3}+\mathbf{e}
$$

Keterangan:

$$
\begin{array}{ll}
\mathrm{Y} & =\text { jumlah penduduk miskin } \\
\mathrm{b}_{0} & =\text { konstanta } \\
\mathrm{b}_{1}, \mathrm{~b}_{2}, \mathrm{~b}_{3}, & =\text { parameter } \\
\mathrm{X}_{1} & =\text { pengangguran } \\
\mathrm{X}_{2} & =\text { upah } \\
\mathrm{X}_{3} & =\text { Produk Domestik Regional Bruto } \\
\mathrm{e} & =\text { error term }
\end{array}
$$

Dalam penelitian ini dengan menggunakan data panel, minimal ada tiga prosedur edtimasi untuk mengetahu model terbaik yang digunakan, antara lain:

- $\quad$ Pooled OLS

- $\quad$ Fixed Effect (Covariance Model)

- Random Effect (Error Component Model)

\section{Uji Statistik}

Uji statistik terdiri dari uji pengaruh secara bersama-sama (uji F), uji secara parsial (uji t), dan koefisien determinasi $\left(\mathrm{R}^{2}\right)$.

\section{Uji Asumsi Klasik}

Uji ini merupakan uji terhadap kriteria ekonometrika yang meliputi uji multikolinearitas dan uji normalitas. Pengujian asumsi ini bertujuan untuk melihat apakah estimasi dari model regresi yang diperoleh tidak bias dan bersifat BLUE (Best Linier Unbiased Estimator).

\section{Hasil dan Pembahasan}

\section{Hasil}

\section{Analisis Regresi Data Panel}

Berdasarkan analisis regresi data panel dengan mengguanakan fixed effect model maka dapat diperoleh hasil sebagai berikut:

1. Besarnya hasil dari koefisien regresi yaitu sebesar 7,007489 persen artinya apabila jumlah pengangguran, upah, dan Produk Domestik regional bruto (PDRB) dalam keadaan konstan maka jumlah penduduk miskin yang ada yaitu sebesar 7,007489 persen.

2. Pengaruh variabel jumlah pengangguran terhadap variabel jumlah penduduk miskin kemiskinan yaitu sebesar 0,077316 persen ditunjukan dengan X1, artinya apabila jumlah pengangguran naik sebesar 1 persen maka jumlah penduduk miskin akan mengalami kenaikan sebesar 7,7 persen.

3. Pengaruh variabel upah terhadap variabel jumlah penduduk miskin yaitu sebesar -0,069549 persen ditunjukan dengan $\mathrm{X} 2$, artinya apabila tejadi kenaikan upah sebesar 1 persen maka akan mengakibatkan terjadinya penurunan jumlah penduduk miskin sebesar 6,9 persen.

4. Pengaruh variabel Produk Domestik Regional Bruto (PDRB) terhadap variabel jumlah penduduk miskin yaitu 
sebesar -0,142782 persen ditunjukan dengan X3, artinya apabila terjadi kenaikan angka Produk Domestik Regional Bruto (PDRB) sebesar 1 persen maka akan mengakibatkan terjadinya penurunan jumlah angka penduduk miskin yaitu sebesar 14,2 persen

\section{Uji Statistik}

Uji F

Uji $F$ adalah bagian dari uji statistik yang digunakan untuk mengetahui dan mengukur signifikansi antara variabel bebas (independen) yaitu pengangguran, upah dan PDRB terhadap variabel terikat (dependen) kemiskinan. Dalam uji $\mathrm{F}$ dapat diketahui pengaruh variabel independen terhadap variabel dependen secara simultan. Kriteria pengujian dalam Uji Fstatistik sebagai berikut:

1. Dengan tingkat keyakinan $\alpha 5 \%$, jika nilai F-statistik $>$ Ftabel atau nilai probabilitas $\mathrm{F}$ statistik $<$ nilai probabilitas $\alpha$ maka $\mathrm{H}_{\mathrm{o}}$ diterima dan $\mathrm{H}_{\mathrm{a}}$ ditolak.

2. Dengan tigkat keyakinan $\alpha 5 \%$, jika nilai F-statistik $<$ Ftabel atau nilai probabilitas $\mathrm{F}$ statistik $>$ nilai probabilitas $\alpha$ maka $\mathrm{H}_{\mathrm{o}}$ diterima dan $\mathrm{H}_{\mathrm{a}}$ ditolak.

Hasil analisis menunjukkan bahwa uji $\mathrm{F}$ probabilistik sebesar $0,00000<0,05$ yang berarti bahwa variabel independen (pengangguran, upah dan PDRB) memiliki pengaruh yang signifikan terhadap variabel dependen (kemiskinan)

Uji t

Uji t adalah uji yang dilakukan untuk mengetahui pengaruh variabel independen yaitu pengangguran, upah, dan PDRB terhadap variabel dependen yaitu kemiskinan secara parsial atau individual.

1. Dengan tingkat keyakinan $\alpha=5 \%$ jika nilai probabilitas $\mathrm{t}_{\text {hitung }}<$ tingkat signifikansi $5 \%(0,05)$ atau $\mathrm{t}_{\text {hitung }}>\mathrm{t}_{\text {tabel }}$ maka $\mathrm{H}_{\mathrm{o}}$ ditolak dan $\mathrm{H}_{\mathrm{a}}$ diterima.

2. Dengan tingkat keyakinan $\alpha=5 \%$ jika nilai probabilitas $\mathrm{t}_{\text {hitung }}>$ tingkat signifikansi $5 \%(0,05)$ atau $\mathrm{t}_{\text {hitung }}<\mathrm{t}_{\text {tabel }}$ maka $\mathrm{H}_{\mathrm{o}}$ diterima dan $\mathrm{H}_{\mathrm{a}}$ ditolak.

1. Pengangguran memiliki pengaruh positif signifikan terhadap kemiskinan di Jawa. Kondisi ditunjukkan dengan nilai $\mathrm{t}$ probabilistik sebesar $0,0030<0,05$. Sehingga ketika terjadi penurunan pengangguran $\mathrm{m}$ aka kemiskinan juga akan turun dan sebaliknya jika pengangguran meningkat maka kemiskinan juga meningkat.

2. Upah memiliki pengaruh negatif signifikan terhadap kemiskinan. Kondisi ini ditunjukkan dengan nilai $t$ probabilistik $0,0000<0,05$. Sehingga ketika terjadi kenaikan upah maka kemiskinan akan menurun dan sebaliknya jika upah menurun maka kemiskinan akan semakin meningkat.

3. PDRB memiliki pengaruh negatif signifikan terhadap kemiskinan. Hal ini ditunjukkan dengan nilai $t$ probabilistik sebesar $0,0000<0,05$ yang berarti bahwa ketika terjadi kenaikan PDRB maka kemiskinan akan turun, dan sebaliknya jika terjadi penurunan PDRB maka kemiskinan akan meningkat

Uji $R^{2}$

Koefisien determinan $\mathrm{R}^{2}$ bertujuan untuk mengetahui besarnya jumlah sumbangan dari variabel independen terhadap variabel dependen atau mengukur seberapa besar proporsi variabel dependen dapat dijelaskan dengan variasi dari variabel terikat. Ketika $R_{2}$ kecil berarti menunjukan bahwa variabel independen dalam menjelaskan variasi variabel dependen sangat terbatas. Sedangkan nilai yang mendekati satu berarti bahwa variabel idependen dapat menjelaskan informasi yang cukup banyak dibutuhkan untuk memprediksi variasi variabel dependen. Hasil analisis menununjukkan bahwa nilai adjusted $\mathrm{R}$ square sebesar 99,6011 yang berarti bahwa sebesar $99,60 \%$ variabel independen berkontribusi dalam memengaruhi variabel independen. Sementara $0,40 \%$ dipengaruhi variabel lain diluar model

\section{Uji Asumsi Klasik}

Uji Multikolinearts

Uji multikolinearitas digunakan untuk mengetahui ada tidaknya hubungan antara variabel independen dalam suatu model regresi. Apabila koefisien korelasi variabel yang bersangkutan nilainya terletak diluar batas penerimaan (critical value) maka koefisien korelasi bermakna dan terjadi multikolinearitas. Untuk mengetahu suatu variabel terkena multikolinearitas ataukan tidak dapat digunakan suatu dasar drajay keyakinan yaitu sebesar 0,8. Apabila angka yang didapati lebih besar dari 0,8 maka variabel tersebut terkena multikolinearitas begitupun pula sebaliknya jika hasil yang diperoleh berada di bawah 0,8 maka variabel tersebut tidak terkena multikolinearitas.

\section{Uji Normalitas}

Uji normalitas dilakukan untuk menguji apakah dalam sebuah model regresi, variabel independen dan variabel dependen mempunyai distribusi normal atau tidak. Regresi yang baik adalah distribusi dan normal atau mendekati normal. Uji normalitas yang dilakukan dengan menetapkan drajat keyakinan yaitu sebesar 0,05

Uji heteroskedastisitas

Heteroskedastisitas muncul apabila kesalahan atau residual dari modelyang diamati tidak memiliki varians yang konstan dari satu observasi ke observasi lainnya. Artinya, setiap observasi mempunyai reliabilitas yang berbeda akibat perubahan dalam kondisi yang melatarbelakangi tidak terangkum dalam spesifikasi model.

Uji Aautikolerasi uji autokolerasi yang dilakukan dengan menggunakan uji Durbin-Watson uji ini digunakan unutk mendeteksi adanya korelasi antar anggota serangkaian observasi time series dan cross section

\section{Pembahasan}

Penelitian ini bertujuan untuk mengetahui dan menganalisis pengaruh pengangguran, upah dan PDRB terhadap kemiskinan di Jawa. Sebelum membahas mengenai hasil uji statistik, penelitian ini menggunakan data panel sehingga perlu memilih model terbaik dari tiga metode yaitu Pooled Least Square (PLS), Fixed Effect Model (FEM) dan Random Effect Model (REM).Hasil estimasi yang didapat dari pengujian pertama yaitu menguji antara metode Pooled Least Square dan Fixed Effect Model dengan menggunakan uji Chow dimana hasil menunjukkan nilai probabilitas chi- 
square lebih kecil dibandingkan dengan probabilitas kritis $(\alpha$ $=5 \%=0,05)$ sehingga model Fixed Effect Model yang menjadi model terbaik. Kemudian dilanjutkan dengan uji Hausman dimana menguji pendekatan Random Effect Model dan Fixed Effect Model yang hasilnya menunjukkan bahwa nilai probabilitas chi-square lebih kecil dibandingkan dengan probabilitas kritis $(\alpha=5 \%=0,05)$ sehingga model Fixed Effect Model yang terpilih menjadi model terbaik untuk penelitian ini.

Berdasarkan hasil analisis regresi, selanjutnya dapat dibahas tentang faktor yang mempengaruhi kemiskinan di Jawa.

1. Hubungan pengangguran dengan kemiskinan dalam Lincolind Arsyad (1997) menyatakan bahwa ada hubungan yang erat sekali antara tingginya tingkat pengangguran dan kemiskinan. Bagi sebagian besar masyarakat, yang tidak mempunyai pekerjaan tetap atau hanya part-time selalu berada diantara kelompok masyarakat yang sangat miskin. Masyarakat yang bekerja dengan bayaran tetap di sektor pemerintah dan swasta biasanya termasuk diantara kelompok masyarakat kelas menengah keatas. Setiap orang yang tidak mempunyai pekerjaan adalah miskin, sedangkan yang bekerja secara penuh adalah orang kaya. Karena terdapat pekerja diperkotaan yang tidak bekerja secara sukarela karena mencari pekerjaan yang lebih baik dan yang lebih sesuai dengan tingkat pendidikannya. Mereka menolak pekerjaanpekerjaan yang mereka rasakan lebih rendah dan mereka bersikap demikian karena mereka mempunyai sumber-sumber lain yang bisa membantu masalah keuangan mereka. Orangorang seperti ini bisa disebut menganggur tetapi belum tentu miskin. Hasil dari penelitian ini menunujukan adanya hubungan yang positif antara pengangguran terhadap kemiskinan sesuai dengan teori diatas sebesar 0,077316 persen yang artinya setiap ada kenaikan pengangguran sebesar 1 persen maka akan menyebabkan terjadinya keniakan jumlah kemiskinan sebesar 0,077316 persen serta memiliki nilai probabilitas sebesar 0,0030 yang menunujukan bahwa pengangguran berpengaruh positif dan signifikan terhadap kemiskinan. Penelitian sebelumnya yang telah dilakukan oleh (Martiyan Ramadani, 2015) dimana hasil yang didapati yaitu sebesar 1,13 yang artinya jika pengangguran naik sebesar 1 persen maka akan menyebabkan terjadinya kenaikan penduduk miskin sebesar 1,13 juta jiwa hal ini mengakibatkan hilangnya pendapatan seseorang sehingga menjadikan mereka tidak bisa memnuhi kebutuhannya dan akhirnya menjadi penduduk miskin serta nilai probabilitas sebesar 0,00 menunjukan bahwa pengangguran berpengaruh positif dan signifikan terhadap jumlah penduduk miskin karena nilai probabilitasnya kurang dari $\alpha=0,05$.

2. Hubungan upah dengan kemiskinan Upah dan pengangguran memiliki keterkaitan yang cukup erat dimana tinggi rendahnya upah akan mempengaruhi jumlah penawaran dan permintaan tenaga kerja yang pada akhirnya akan berdampak pada jumlah pengangguran. Upah merupakan pembayaran jasa-jasa fisik maupun mental kepada tenaga kerja. Upah uang yaitu jumlah uang yaitu diterima pekerja dari pengusaha sebagai pembayaran atas tenaga mental dan fisik yang digunakan dalam proses produksi apabila jumlah upah yang dibayarkan semakin besar makan akan semakin besar konsumsi yang dilakukan oleh0" masyarakat untuk memenuhi kebutuhannya sehingga jumlah penduduk miskin yang ada akan berkurang. (Sukirno dalam I Made Yogatama, 2010: 24). Sesuai dengan pernyataan diatas hasil dalam penelitian ini menunujukan hasil yang negatif sebesar $-0,069549$ persen yang artinya apabila terjadi kenaikanupah sebesar 1 persen maka akan menyebabkan terjadinya penurunan jumlah penduduk miskin sebesar 0,069549 persen serta memiliki nilai probabilitas sebesar 0,00 yang menunujukan bahwa upah berpengaruh negatif dan signifikan terhadap kemiskinan. Penelitian sebelumnya yang dilakukan oleh (Okta Ryan Pranata Yudha, 2013) memiliki hasil yang berbeda dengan yang peneliti lakukan hal ini terbukti dengan berpengaruh positif dan signifikan upah terhadap kemiskinan sebesar 0,045931 dan probabilitas sebesar 0,0481. Hasil terebut tidak sesuai dengan hipothesis penelitian yang menyatakan bahwa upah berpengruh negatif dan signifikan terhadap kemiskinan, hal tersebut dikarenakan sektor terbesar yang mendorong perekonomian adalah sektor pertanian atapaun sektor informal karena upah hanya berlaku pada sektor formal atau perdagangan.

3. Hubungan PDRB dengan kemiskinan berkaitan erat Menurut Kuncoro (2001) pendekatan pembangunan tradisional lebih dimaknai sebagai pembangunan yang lebih memfokuskan pada peningkatan PDRB suatu provinsi, kabupaten, atau kota. Menurut Sadono Sukirno (2000), laju pertumbuhan ekonomi adalah kenaikan PDRB tanpa memandang apakah kenaikan itu lebih besar atau lebih kecil. Selanjutnya pembangunan ekonomi tidak semata-mata diukur berdasarkan pertumbuhan produk domestik regional bruto (PDRB) secara keseluruhan, tetapi harus memperhatikan sejauh mana distribusi pendapatan telah menyebar ke lapisan masyarakat serta siapa yang telah menikmati hasil-hasilnya. Sehingga menurunnya PDRB suatu daerah berdampak pada kualitas dan pada konsumsi rumah tangga. Dengan turunyya pendapatan masyarakat maka akan dapat mengakibatkan masyarakat tersebut tidak mampu untuk memenuhi kebutuhannya serta dapat mengakibatkan terjadinya kemiskinan. Berdasarkan pendapat diatas penelitian ini sesuai dengan teori yang ada karena dari hasil yang didapat sebesar $-0,142782$ persen serta probabilitas sebesar 0,00 artinya setip terjadi kenaikan PDRB sebesar 1 persen maka dapat menyebabkan terjadinya penurunan jumlah penduduk miskin sebesar 0,142782 persen. Serta berpengaruh secara signifikan terhadaap kemiskinan. Penelitian yang dilakukan oleh (Ravi Dwi Wijayanto, 2010) memiliki hasil yang berbeda dengan peneliti yitu hasil pada analisis data panelnya sebesar -0,076 dan probabilitas sebesar 0,162 yang artinya setiap terjadi kenaikan PDRB sebesar 1 persen maka akan menyebabkan terjadinya penurunan jumlah penduduk miskin sebesar 0,076 persen namun memiliki nilai probabilitas yang besar dan tidak sama dengan hasil peneliti yang memiliki hasil tidak signifikan, ketidaksignifikannya PDRB tersebut karena tidak selalu terjadi kenaikan PDRB tidak selalu diikuti dengan terjadinya penurunan kemiskinan pada penelitian yang dilakukan.

\section{Simpulan}

Berdaasarkan hasil analisis dan pembahasanyang telah diuraikan, maka dapat mengambil simpulan bahwa 
pengangguran, upah, dan PDRB berpengaruh secara individu dan secara serentak positif terhadap kemiskinan di Jawa dan dinyatakan dapat diterima, artinya semakin besar pengangguran maka akan semakin besar pula jumlah penduduk miskin yang ada di Jawa serta semakin besar upah dan PDRB maka akan semakin kecil jumlah penduduk miskin yang ada di Jawa.

Berdasarkan hasil penelitian, saran-saran yang dapat diberikan adalah pemerintah pada masing-masing provinsi haarus dapat mencipkan iklim yang sesuai dengan keadaan yang dibutuhkan pada masing-masing provinsi. Peningkatan lapangan pekerjaan menjaadi hal yang perlu dikembangkan secara serius untuk dapat mengatasi masalah pengangguran agar nantinya diharpkan masyarakat mampu untuk mencari kerja serta memiliki pendapatan agar dapat memenuhi standar kebutuhan hidupnya.

\section{Referensi}

Djojohadikusumo, Sumitro. 1994. Perkembangan Pemikiran Ekonomi Dasar Teori Pertumbuhan dan EkonomiPembangunan. Jakarta: Penerbit LP3ES

Fitri, Reni Mustika. 2012. Pengaruh kualitas sumber daya manusia, pertumbuhan ekonomi, dan Rasio Gender Terhadap Tingkat Kemiskinan di Provinsi Sumatera Barat. Padang: Fakultas ekonomi Universitas Negeri Padang.

Hutama, Henggarsyah Aria. 2015. Strategi penanggulangan Kemiskinan Di Kabupaten Jember (Aplikasi Analitycal Hierarchy Process). Jember: Fakultas Ekonomi Universitas Jember

Kristanto, Prabowo Dwi. 2014. Analisi Pengaruh Pertumbuhan EkonomiI,
Upah Minimum dan Tingka Pengangguran Terhadap Jumlah Penduduk Miskin di Kabupaten Brebes Tahun 1997-2012. FEB.UNDIP

Mira, Denni Sulistio, 2012. Pengaruh kemiskinan, pertumbuhan ekonomi, dan belanja modal terhadap indeks pembangunan manusia di Jawa tengah tahun 2006-2009.Semarang: Fakultas Ekonomi Universitas Negeri Semarang.

Nugroho, Priyo Adi. 2015. Pengaruh PDRB, Tingkat pendidikan, dan Pengangguran terhadap kemiskinan di kota Yogyakarta. Yogyakarta: Fakultas Ekonomi Universitas Negeri Yogyakarta.

Ramdani, Martiyan. Determinan Kemiskinan di Indonesia Tahun 1982-2012. Semarang: Fakultas Ekonomi Universtas Negeri Semarang

Siregar, Hermanto dan Wahyuniarti, Dwi. Dampak Pertmbuhan Ekonomi Terhadap Penurunan Jumlah Pendudu Miskin. Direktur Akademik MB$I P B$

Sukmaraga, Prima. 2011. Analisis Pengaruh Indeks Pembangunan Manusia, PDRB perkapita, dan jumlah Pengangguran terhadap jumlah penduduk miskin di Provinsi Jawa Tengah. Semarang: Fakultas Ekonomi Universitas Diponegoro.

Wahyudi, Dicky dan Rejekiningsih, Tri Wahyu. 2013. Analisis kemiskinan di Jawa Tengah. Semarang: Fakultas Ekonomika dan Bisnis Universitas Diponegoro

Wiguna, Van Indra. 2013. Analisis Pengaruh PDRB, Pendidikan, dan Pengangguran Terhadap Kemiskinan di Provinsi Jawa Tengah Tahun 2005-2010. Malang: Fakultas Ekonomi dan Bisnis Universitas Brawijaya

Wijayanto, Ravi Dwi. 2010. Analisis Pengaruh PDRB, Pendidikan dan Pengangguran Terhadap Kemiskinan di Kabupaten/Kota Jawa Tengah. Fakultas Ekonomi Universitas Diponegoro Semarang.

Yudha, Okta Ryan Pranata. 2013. Pengaruh Pertumbuhan Ekonomi, Upah Minimum dan Pengangguran Terhadap Kemiskinan di Indonesia 2009. 2011. 